\title{
Current Research on Artificial Arsenic Sulphide Pigments in Artworks: A Short Review
}

\author{
Günter Grundmann ${ }^{\star a}$ and Mark Richter ${ }^{\mathrm{b}}$
}

\begin{abstract}
A general re-examination of the artificial arsenic sulphide pigments orpiment, realgar and alacranite using polarised light microscopy (PLM), scanning electron microscopy (SEM) combined with energy and wavelength dispersive X-ray analysis (EDX, WDX) and X-ray diffraction analysis (XRD) revealed the following results: wet-process precipitation products of artificial orpiment consist of golden yellow, amorphous, spherical particles ranging from 0.2 to $2 \mu \mathrm{m} \varnothing$. Dry-process roasting and/or sublimation products with an arsenolite/sulphur mixture consist mainly of amorphous golden yellow oval drops and spherules of amorphous arsenic sulphide glass $\left(g-A s_{x} S_{x}\right)$ with a smooth surface ranging from 1 to $20 \mu \mathrm{m} \varnothing$ in association with arsenolite crystal aggregates and members of the alacranite solid solution series $\left(\mathrm{As}_{8} \mathrm{~S}_{8}\right)-\left(\mathrm{As}_{8} \mathrm{~S}_{9}\right)$. A bright lemon yellow to orange-red arsenic sulphide pigment on a sixteenth/seventeenth-century South German polychrome recumbent sculpture and a seventeenth-century Dutch painting attributed to Rembrandt's studio has been identified as an artificial orpiment produced with dry-process (roasting/sublimation) methods. The recumbent figure contains (i) yellow, orange or red-brown amorphous splintery fragments and spherules of arsenic sulphide glass of up to $25 \mu \mathrm{m} \varnothing$, (ii) yellow, brown or red-brown crystalline spherules and splintery fragments of alacranite, (iii) lemon yellow to red-brown agglomerates of arsenic sulphide glass, and (iv) colourless irregular fragments or octahedral crystals of arsenolite. This type can be classified as 'complex artificial orpiment'. The arsenic sulphide pigment in the yellowish paint layers of the Rembrandt studio painting proved to be very uniform bright yellow spherules (max. $9 \mu \mathrm{m} \varnothing)$ of arsenic sulphide glass, which can be classified as 'purified artificial orpiment glass'. A deep red historic arsenic sulphide cake from the collection of the Landesmuseum Joanneum (Graz, Austria) called 'Realgar' turned out to be an amorphous arsenic sulphide glass matrix (approx. $\mathrm{g}-\mathrm{As}_{2} \mathrm{~S}_{3}$ ) filled with numerous red crystal aggregates of alacranite (approx. $\mathrm{As}_{8} \mathrm{~S}_{9}$ ) in the form of spherules, which fill gas bubbles and pores with an average $3 \mu \mathrm{m} \varnothing(\max .20 \mu \mathrm{m} \varnothing)$. A very fine-grained light red arsenic sulphide powder called 'Realgar' from an archaeological excavation of a historic arsenic smelter near Strassegg (Steiermark, Austria) turned out to be a member of the alacranite solid solution series $\left(\mathrm{As}_{8} \mathrm{~S}_{8}\right)-\left(\mathrm{As}_{8} \mathrm{~S}_{9}\right)$ in the form of idiomorphic crystals and complex twinned crystal aggregates (average $10 \mu \mathrm{m} \varnothing$, max. $30 \mu \mathrm{m} \varnothing$ ). All red-colored crystals or crystal aggregates of artificial arsenic sulphides that have been called 'realgar' in the past are in fact members of the alacranite solid solution series. The occurrence of pararealgar as a secondary photochemical reaction product is not exclusively linked with realgar, but can also form on members of the alacranite solid solution series $\left(\mathrm{As}_{8} \mathrm{~S}_{8}\right)-\left(\mathrm{As}_{8} \mathrm{~S}_{9}\right)$.
\end{abstract}

Keywords: Alacranite · Artificial arsenic sulphide pigments · Orpiment · Painting · Polychromy $\cdot$ Realgar

${ }^{\text {*Correspondence: }}$ Dr. rer. nat. G. Grundmann ${ }^{2}$

aTechnische Universität München

Lehrstuhl für Ingenieurgeologie

Arcisstr. 21

D-80333 München

Tel : +498928925831

Fax: +49 89 289-25852

E-Mail: g.grundmann@tum.de

bTechnische Universität München

Lehrstuhl für Restaurierung, Kunsttechnologie und

Konservierungswissenschaft

DFG Research Project 'Polychromy'

Oettingenstr. 15

D-80538 München

\section{Introduction}

The minerals orpiment and realgar belong to a small group of sulphides with a nonmetallic character. Both were considered important pigments and were in use until the end of the nineteenth-century.[1] The natural occurrences, however, never supplied enough material in order to be able to even roughly meet the large demand of the golden yellow and red colorants. The foliaceous, mica-like tough consistency of the coarse orpiment required a great deal of effort during pulverising and grinding. Its sparse occurrence as a deposit and the problems encountered by the preparation of a pure product might have been the true incentive to replace the bright yellow pigment with an equally homogeneous artificial product in Antiquity. The production numbers of arsenolite smelters (production of synthetic arsenolite $=$ arsenic trioxide $=$ $\mathrm{As}_{2} \mathrm{O}_{3}$ ) as well as the distribution and economic use of their products revealed that hundreds of tonnes of artificially prepared yellow and red arsenic sulphides, besides the main product artificial arsenolite, must have been available during a period of more than 350 years ending with World War II. ${ }^{[2]}$ Beyond this its use as a versatile colorant is documented in historical documentary sources (e.g. treatises, handbooks, manuals, encyclopaedias and pharmacy price-lists). According to Wallert ${ }^{[3]}$ and 
FitzHugh $^{[4]}$ only orpiment, realgar, pararealgar and alacranite (see Popova et al. ${ }^{[5]}$ ) have been identified on cultural property. Wallert ${ }^{[3]}$ and FitzHugh ${ }^{[4]}$ also supplied the first approaches for the identification of artificial orpiment and realgar in modern art technology. Compared to realgar the very similar and in nature very rare arsenic sulphide alacranite was identified with X-ray diffraction (XRD) and X-ray fluorescence (XRF) in various historical samples of artificial arsenic sulphide pigments. ${ }^{4]} \mathrm{Al}-$ though the morphology, chemical composition and crystal structure of natural arsenic sulphides are well known, their artificial manufactured equivalents are largely considered unexplored. Even the newest encyclopaedias and books for the determination of artists' pigments contain contradictions in view of X-ray diffraction and the chemical and microscopic characteristics of arsenic sulphides. In many cases this literature does not clearly differentiate between IMA-proved mineral species names (verified by IMA = International Mineralogical Association), which are naturally in a crystalline state (e.g. realgar), and their isotropic amorphous artificial equivalents. ${ }^{[6]}$

In this article the basic criteria for the distinction of the natural and artificial arsenic sulphides orpiment, realgar and alacranite are presented and made possible with the discovery and investigation of historical and modern reference samples.

\section{The Arsenic-Sulphur System}

The As-S system includes three congruently melting stable crystalline phases at arsenic/sulphur ratios of 4:3, 4:4 and 2:3. ${ }^{[7]}$ The natural mineral equivalents are dimorphite $\left(\mathrm{As}_{4} \mathrm{~S}_{3}\right)$, realgar or pararealgar $\left(\mathrm{As}_{4} \mathrm{~S}_{4}\right)$, and orpiment $\left(\mathrm{As}_{2} \mathrm{~S}_{3}\right)$. The arsenic sesquisulphide, $\mathrm{As}_{2} \mathrm{~S}_{3}$, occurs in three crystalline polymorphs: $\alpha, \beta$ and $\gamma \cdot{ }^{[7]}$ The $\beta$ and $\gamma$ polymorphs are only stable under high pressure conditions. The $\alpha$-phase is equivalent to the mineral orpiment and undergoes no polymorphic transformations during heating under normal conditions. With a melting temperature at $580 \pm 3 \mathrm{~K}$ $\left(318^{\circ} \mathrm{C}\right)$ realgar and orpiment are reported to sublimate congruently, which means that during sublimation its chemical composition does not change. [7]

The natural arsenic sulphide realgar is the low-temperature form of ' $\mathrm{As}_{4} \mathrm{~S}_{4}{ }^{\prime} \cdot{ }^{[8-10]}$ The red mineral alacranite, which is very similar to realgar (idealised chemical formula $\mathrm{As}_{8} \mathrm{~S}_{9}$, type locality Alacran mine in Kamchatka) is in comparison rarely found in nature and occurs only in microscopically small quantities. ${ }^{[5]}$ Derived from burning coal beds or pit fires the tabular alacranite crystals, which often occur together with the mineral arsenolite $\left(\mathrm{As}_{2} \mathrm{O}_{3}\right)$ can reach a length of up to several millimetres. Prior to the first description of alacranite by Popova et al. ${ }^{[5]}$ it was called 'natural and synthetic arsenic sulphide' realgar and classified as 'alpha- $\mathrm{As}_{4} \mathrm{~S}_{4}$ ' by Clark, [11] as 'beta- $\mathrm{As}_{4} \mathrm{~S}_{4}$ ' unnamed' by Porter and Sheldrick ${ }^{[12]}$ and as ' $\mathrm{As}_{2} \mathrm{~S}_{2,15}$ ' by Kothiyal and Gosh. ${ }^{[13]}$ However, Bonazzi et al. ${ }^{[14]}$ discovered that the prefixes alpha and beta were used inconsistently in these works, and therefore designated the natural low-temperature form (realgar) as 'alpha- $\mathrm{As}_{4} \mathrm{~S}_{4}$ ' and the natural high temperature form ${ }^{[11]}$ and/or synthetic high temperature form ${ }^{[12]}$ as 'beta- $\mathrm{As}_{4} \mathrm{~S}_{4}$-unnamed'. In addition the investigations of Bonazzi et al. ${ }^{[14]}$ also clarified for the first time the complicated structural relations between the natural and synthetic products using the general formula $\mathrm{As}_{4} \mathrm{~S}_{4}$ and the natural alacranite sensu stricto $\mathrm{As}_{8} \mathrm{~S}_{9}$. According to a comparison of the elementary cell volumes of a further new discovery of alacranite sensu stricto (Kateřina Mine, Czech Republic) Bonazzi et al. ${ }^{[14]}$ come to the conclusion that a continuous solid solution series must be present between the high temperature form ('beta- $\mathrm{As}_{4} \mathrm{~S}_{4}$-unnamed') and the mineral alacranite sensu stricto $\left(\mathrm{As}_{8} \mathrm{~S}_{9}\right)$. This makes it possible to assume that many if not all of the substances that were earlier called 'alacranite', 'artificial realgar', 'rotes Arsenglas' or 'Rotglas' are in fact members of the alacranite solid solution series $\left(\mathrm{As}_{8} \mathrm{~S}_{8}\right)$ $\left(\mathrm{As}_{8} \mathrm{~S}_{9}\right)$. If the cell volumes between these two crystal structures shift, then the dimensions of the unit cells and accordingly the diffraction angles ( 2 theta, $\mathrm{Cu}-\mathrm{K}$-alpha) as well as the similar d-values (lattice plane distances) also change significantly. The optical properties of the alacranite solid solution series $\left(\mathrm{As}_{8} \mathrm{~S}_{8}\right)-\left(\mathrm{As}_{8} \mathrm{~S}_{9}\right)$ and realgar $\left(\mathrm{As}_{4} \mathrm{~S}_{4}\right)$ are almost identical. Thus it is not possible to allocate these arsenic sulphides accurately without proper X-ray diffraction and/or crystal structural analytical data In the phase diagram of the binary $\mathrm{As}_{\mathrm{x}}$ $\mathrm{S}_{\mathrm{x}}$ system (Massalski, ${ }^{[15]}$ Emelina et al. ${ }^{\mathrm{x}]}$ ) the transition temperature from liquidus to solidus of the arsenic sulphides realgar and orpiment is around $318{ }^{\circ} \mathrm{C}$, whereas, for dimorphite I and II the transition temperature is around $200{ }^{\circ} \mathrm{C}$. Emelina et al. (2007) concluded that crystalline $\mathrm{As}_{4} \mathrm{~S}_{3}, \mathrm{As}_{4} \mathrm{~S}_{4}$ and $\mathrm{As}_{2} \mathrm{~S}_{3}$ sublimate congruently and that two liquid-vapour azeotropes exist in the As-S system. ${ }^{[7]}$ This azeotropic behaviour could be an explanation for the often observed complex mixture of amorphous arsenic sulphide glasses, alacranite and dimorphite I in artificial arsenic sulphide cakes. The high viscosity of arsenic sulphide melts, which have nearly the same chemical composition as natural orpiment, drastically reduces the nucleation rate of artificial orpiment during rapid cooling. The behaviour of this type of molten arsenic sulphide suspends the new growing orpiment crystals. For thermody- namic reasons it appears improbable that artificial orpiment crystals with the properties of natural orpiment can develop in arsenic sulphide cakes which solidify rapidly.

\section{Microscopic, Diffractometric and Chemical Characteristics of Artificial Arsenic Sulphides}

A total of eight varieties of artificial arsenic sulphides from historic and modern synthesis products were studied with polarised light microscopy, scanning electron microscopy, X-ray diffraction as well as electron beam microprobe methods and compared to natural orpiment. Five synthesis test series for the preparation of artificial orpiment were carried out under atmospheric conditions to produce on the one hand precipitations with the wet-process methods using (I) - thioacetamide and (II) - hydrogen sulphide, and on the other hand cakes and/or sublimates with the dry-process methods using (III) - natural orpiment, (IV) - natural orpiment and additional synthetic arsenolite, and (V) - substance mixtures of synthetic arsenolite and sulphur. ${ }^{[2]}$

The wet-process precipitated product obtained using hydrogen sulphide (II) revealed golden yellow, spherical arsenic sulphide particles with an average size of $0.2 \mu \mathrm{m}$ (maximum $0.4 \mu \mathrm{m}$ ), which are in an order of magnitude smaller than the golden yellow, spherical arsenic sulphide particles obtained using thioacetamide (I) with an average size of $1 \mu \mathrm{m}$ (maximum $2 \mu \mathrm{m}$ ).

The dry-process synthesis products obtained from various starting materials including natural orpiment (III, IV) are generally a mixture of colourless, octahedral arsenolite crystals $\left(\mathrm{As}_{2} \mathrm{O}_{3}\right)$ and yellow to brown glassy arsenic sulphide particles $\left(\mathrm{As}_{2} \mathrm{~S}_{3}\right)$ with a chemical composition identical to natural orpiment. This mixture often contains crystalline lamellar-foliated relicts of natural orpiment. Natural orpiment possesses a pronounced layer-lattice structure similar to the minerals talc, graphite and molybdenite. The crystalline character of natural orpiment is verifiable both with polarised light microscopy (due to the anisotropy effects and interference colours) and $\mathrm{X}$-ray diffraction methods (XRD). Natural orpiment particles are characterised by their typical angular and lamellar-foliated morphology. Ductile deformation structures observed on single particles include compressed corners, edges and tight folds, which sometimes result in complex creased structures.

Artificial orpiment glass, manufactured by the dry-process roasting method exclusively with finely pulverised natural orpiment (III), normally forms a yellowishbrown, glassy mass or cake and/or sublimates whose glass proportion appear iso- 
tropic and amorphous using polarised light microscopy (PLM) and X-ray diffraction (XRD). The sublimate consists of yellow smooth, round drops and spherules, as is the case with the other sublimates of artificial orpiment.

Artificial arsenic sulphide particles obtained by the dry-process methods of roasting and sublimating a mixture of artificial arsenolite and natural orpiment (IV) are made up of the same components as described in the previous cases.

Artificial arsenic sulphide particles produced by sublimation with arsenolite and sulphur (V) consist mainly of a mixture of colourless transparent arsenolite crystal aggregates, often as sharp-edged octahedra, and golden-yellow to yellow-brown, highly refractive, oval drops and spherules with a smooth surface. With the aid of polarised light microscopy these glassy particles generally appear isotropic and are X-ray amorphous.

The products of the various dry-process methods revealed yellow spherical particles with an average size of $4 \mu \mathrm{m}$ (maximum $12 \mu \mathrm{m})$. The sublimated spherules can only be clearly distinguished from those of the wet-process methods if (apart from clumped aggregates) the particle size of the yellow amorphous arsenic sulphide components is more than $2 \mu \mathrm{m}$. All particles smaller than $2 \mu \mathrm{m}$ look so similar to each other that neither the use of polarised light microscopy (PLM) nor scanning electron microscopy (SEM) can consistently distinguish between the products of the dry and wet-process methods.

It appears improbable that both the dry and wet-process synthesis tests with roasting and/or sublimation under atmospheric conditions can produce crystal types with the characteristic unisotropic properties of natural orpiment. All synthesis products of the dry-process methods where natural orpiment $\left(\mathrm{As}_{2} \mathrm{~S}_{3}\right)$ was not used as a starting material are generally a mixture of crystalline arsenolite $\left(\mathrm{As}_{2} \mathrm{O}_{3}\right)$ and amorphous arsenic sulphide glass $\left(\mathrm{g}-\mathrm{As}_{2} \mathrm{~S}_{3}\right)$ with a chemical composition corresponding largely to natural orpiment. These products sometimes contain traces of members of the alacranite solid solution series $\left(\mathrm{As}_{8} \mathrm{~S}_{8}\right)-\left(\mathrm{As}_{8} \mathrm{~S}_{9}\right)$.

Orange-red lentil-shaped crystals of up to $5 \mathrm{~mm}$ in length on a historic sample of 'artificial realgar' from the collection of the Technische Universität München (special collection of the Swedish mineralogist Dr. Harry von Eckermann, 1886-1969) analysed by X-ray diffraction turned out to be a member of the alacranite solid solution series $\left(\mathrm{As}_{8} \mathrm{~S}_{8}\right)-\left(\mathrm{As}_{8} \mathrm{~S}_{9}\right)$. Microscopic features of the translucent to clear transparent crystal fragments include a clear pleochroism from orange-red to red-brown with an extremely high refractive index. ${ }^{[2]}$ The interference colours (light green to light blue at a thickness of $10 \mu \mathrm{m}$ ) are overlapped by internal reflections, which are especially visible on the edges of thin splinters when viewed under crossed polarisers. X-ray diffraction analysis of orange-yellow, micaceous, crusty fragments on the orange-red alacranite crystal surfaces of the Harry von Eckermann specimen resulted in pararealgar. Yellow fragments of this transition crust show the typical optical characteristics of pararealgar. These pararealgar flakes on the alacranite are interpreted as a secondary photochemical reaction product resulting from a light-induced phase transformation as is already known by natural realgar.

Furthermore, modern, red to orange yellow artificial sulphides cakes from the production of Chinese arsenic smelters were identified as members of the alacranite solid solution series with subordinations of dimorphite I and II. ${ }^{[2]}$ After exposure to a mixture of daylight and artificial light for several months the colour of the red surface altered from light red to orange-yellow. The penetration depth of the colour change reached approximately $0.3 \mathrm{~mm}$ after one year and a fine grained orange-yellow photochemical reaction product with micaceous flakes of up to $1 \mathrm{~mm}$ in size detached from the surface. The orange-yellow flake development exhibiting the optical characteristics of pararealgar was also confirmed by $\mathrm{X}$-ray powder diffraction as pararealgar.

\section{Evidence of Artificial Arsenic Sulphides in Painting and Polychromy}

On the basis of these new results Richter et al. securely identified a dry-process artifi-

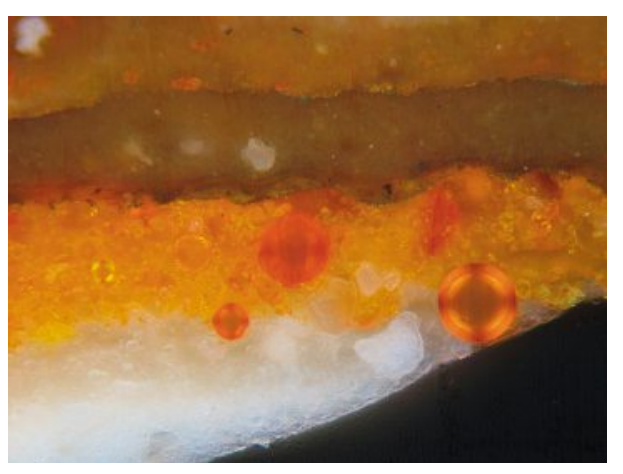

Fig. 1. Polychrome recumbent figure of St. Alto, mitre band, paint cross section with layer build-up of oldest polychromy. Layer build-up from bottom to top: 1) bright lead white ground; 2) bright yellow artificial orpiment layer with spherules (preparatory layer or mordant of gilding); 3) gilding; 4) various overpaintings. The largest spherule measures approx. $30 \mu \mathrm{m}$. Incident light, dark field. Photographer: Dipl.-Rest. Mark Richter, Technische Universität München, Lehrstuhl für Restaurierung, Kunsttechnologie und Konservierung, DFG Research Project 'Polychromy'. cial orpiment on works of art which specifically includes a sixteenth century (?) South German polychrome wooden sculpture and a seventeenth century Dutch painting attributed to Rembrandt's workshop. ${ }^{[16]}$

In the case of the polychrome recumbent sculpture the analysis of the spherulitic particles and splintery fragments within the orange-yellow preparatory layer with SEMEDX revealed two different compositions (Type 1 and Type 2). Light microscopy (cross sections) and polarised light microscopy (dispersed samples) revealed that the spherules of Type 1 and Type 2 exhibit a distinct colour zoning structure from core to rim as well as four segments of a black cross appearing inside the outer rim of the spherules (Fig. 1). Another important discovery of the orangeyellow preparatory layer of the polychrome sculpture are the red-brown spherules and/or splintery (anisotropic, crystalline) fragments of alacranite that have falsely been described in the sources as 'artificial realgar' or 'red orpiment'.

In the case of the painting attributed to Rembrandt's workshop it is striking that all artificial orpiment particles are spherules without any traces of arsenolite. These particles are almost uniform in size, which may suggest that only a carefully washed and levigated sublimate seems to have been used as a pigment. The spherules exhibit identical optical properties (colour zonation, four segments of a black cross appearing inside the outer rim) as the spherulitic particles identified in the orange-yellow paint layer of the recumbent figure. Striking is the almost identical chemical composition of these spherules with the Type 1 particles of the recumbent figure of St. Alto, which suggests the use of a very similar dry-process method to produce amorphous arsenic sulphide spherules. The use of artificial orpiment has until now not been found before in Rembrandt's palette, or in those of his pupils/assistants. The occurrence of orpiment was only reported in Rembrandt's work once, in Simeon's Song of Praise from 1631 (The Hague, Mauritshuis, inv. Nr. 145), but here the natural variant was used.[17] The finding of synthetic orpiment in this painting is even more remarkable, since until this point it has only sporadically shown up in old master paintings. Interesting is another recent discovery by Wallert and Dik of ballshaped arsenic sulphide particles in a yellow layer in a seventeenth century painting by Jan Davidsz De. Heem (Still Life of Flowers and Fruit with Tazza and Birds, oil on canvas, early 1670 s, private collection), which was interpreted as a deterioration product. [18] Neither X-ray diffraction (XRD) nor electron diffraction analysis could identify any phases in a crystalline state. ${ }^{[18,19]}$ This example of a spherical amorphous arsenic sulphide can be interpreted as a dry-process product as described above. 


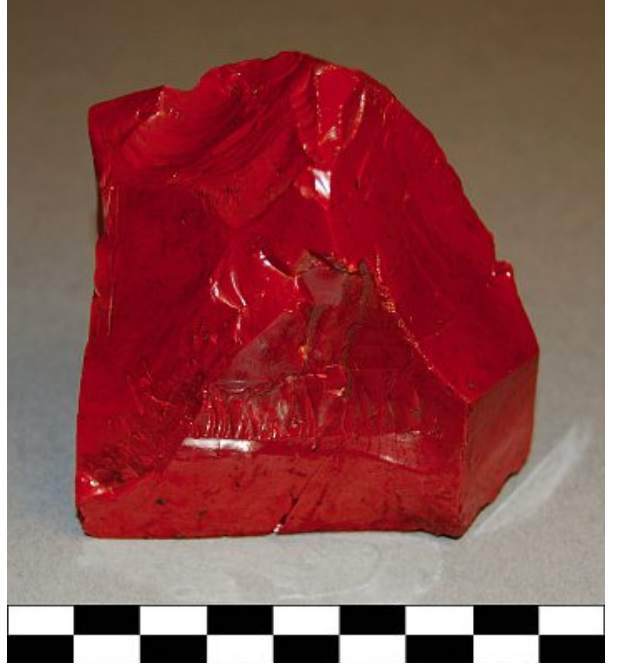

Fig. 2. Fragment of artificial arsenic sulphide cake 'Realgar, Rotglas' (scale bar in $\mathrm{cm}$ ) produced in the famous arsenic smelter of Muldenhütten near Freiberg, Saxony (Germany) before 1867. This specimen was documented in 1867/68 as part of the inventory of the Joanneum collection in Graz, Austria. Photographer: Daniel Modl, Landesmuseum Joanneum, Graz.

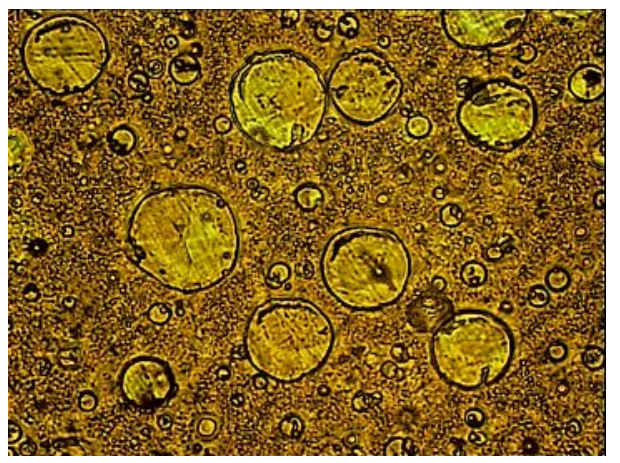

Fig. 3. Artificial arsenic sulphide cake Realgar 'Realgar, Rotglas', polished thin section with a thickness of $10 \mu \mathrm{m}$, transmitted light 1 Polar, width of image: $0.12 \mathrm{~mm}$. Round orange-red particles of alacranite floating in an orangered matrix of arsenic sulphide glass (approx. $\mathrm{g}-\mathrm{As}_{2} \mathrm{~S}_{3}$ ). Photographer: Dr. Günter Grundmann, Technische Universität München, Lehrstuhl für Ingenieurgeologie.

The very complex mixture of various constituents of artificial orpiment identified in the orange-yellow preparatory layer of the polychrome recumbent figure can be classified as the product of multiple synthesis procedures $e . g$. roasting and/or sublimating and grinding. Therefore, it should be called complex artificial orpiment. In the case of the Rembrandt studio painting it is suggested that this very uniform and pure type of spherulitic arsenic sulphide glass should be classified as purified artificial orpiment glass. It should be noted that both terms $p u$ rified artificial orpiment glass and complex artificial orpiment refer specifically to the components present in each sample. The terms orpiment glass and arsenic sulphide glass refer specifically to the solidified arsenic sulphide particles, which are based on the recent thesis by Georgiev ${ }^{[20]}$ and the study by Grundmann and Rötter. ${ }^{[2]}$

New investigations on a historical sample of an artificial arsenic sulphide termed 'Realgar'; the so-called German 'Rotglas' from the mineral collection of the Landesmuseum Joanneum in Graz, Austria (Figs. 2-5) turned out to be a mixture of extremely fine-grained alacranite spherules in an amorphous arsenic sulphide glass matrix and is interpreted as an authentic historical sample of artificial 'realgar'. The spherulitic alacranite fills the pores of solidified gas bubbles in the amorphous arsenic sulphide cake. According to the museum records this deep red artificial arsenic sulphide cake was produced in the famous arsenic smelter of Muldenhütten near Freiberg (Saxony, Germany) before 1867 . This specimen was documented in 1867/68 as part of the inventory (No. 07223) of the Joanneum collection in Graz, Austria. The sample consists of macroscopic homogeneous, deep red, glassy fragments with conchoidal fractures on the surfaces. Microscopic investigations revealed a distinct fluidal texture outlined by the numerous gas bubbles, which are more or less filled by alacranite spherules (Figs. 3-5). These clearly exhibit undulous extinction with light green to light bluegrey interference colours at a thickness of $10 \mu \mathrm{m}$ (under crossed polarisers), which results from radial grown crystal aggregates (Figs. 3 and 4). Rare opaque inclusions are an association of iron sulphide (pyrite?) and zinc sulphide (sphalerite?). Element analyses (SEM-EDX) of the amorphous arsenic sulphide glass matrix resulted in an average chemical composition (resulting from three measurements) of $37.1(+/-2 \%)$ weight $\%$ sulphur and $62.9(+/-2 \%)$ weight $\%$ arsenic, which largely corresponds to the composition of orpiment glass. ${ }^{[2]}$ The alac-

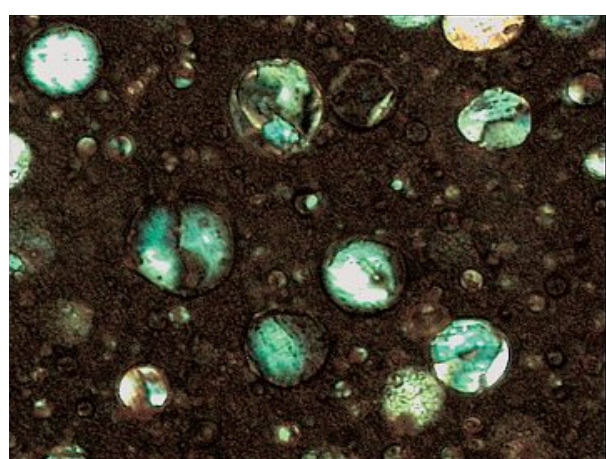

Fig. 4. Artificial arsenic sulphide cake 'Realgar Rotglas', polished thin section with a thickness of $10 \mu \mathrm{m}$, transmitted light crossed polarisers width of image: $0.12 \mathrm{~mm}$. Round particles with light green to light blue-gray interference colours and undulous extinction are alacranite (approx. $\mathrm{As}_{8} \mathrm{~S}_{9}$ ). Photographer: Dr. Günter Grundmann, Technische Universität München, Lehrstuhl für Ingenieurgeologie.

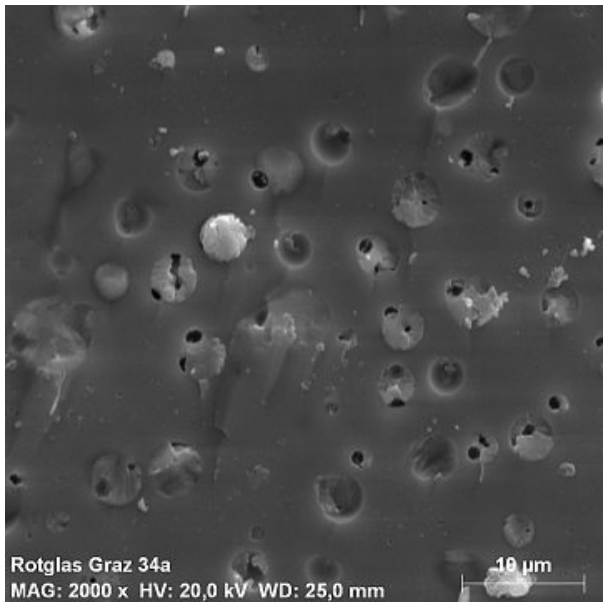

Fig. 5. SEM image of the surface of the artificial arsenic sulphide cake (Specimen number 07223, Joanneum collection in Graz, Austria). The surface revealed gas bubbles, which are more or less filled by alacranite spherules (approx. $\mathrm{As}_{8} \mathrm{~S}_{9}$ ) developing in radial crystal aggregates protruding from the fracture surface of the arsenic sulphide glass matrix (approx. $\mathrm{As}_{2} \mathrm{~S}_{3}$ ). Photographer: Dipl.-Min. Klaus Rapp, Analytical Consultant, Munich.

ranite spherules resulted in an average composition of $31.9(+/-2 \%)$ weight $\%$ sulphur and $68.1(+/-2 \%)$ weight $\%$ arsenic, which largely corresponds to the composition of alacranite sensu stricto $\left(\mathrm{As}_{8} \mathrm{~S}_{9}\right)$.

Microscopic and X-ray powder diffraction analyses of another historic smelter sample of artifical 'realgar' from an archaeological excavation near Strassegg (Steiermark, Austria) by the Bundesdenkmalamt and Landesmuseum Joanneum (Graz, Austria) resulted in an authentic member of the alacranite solid solution series. The sample consists of numerous very small light red crystals and crystal aggregates of up to 30 $\mu \mathrm{m}$ in diameter. Microscopic features of the translucent to clear transparent crystals include a distinct pleochroism from orange-red to red-brown with an extremely high refractive index. There are also indications that this particular smelter produced an extremely fine grained, bright-yellow, amorphous artificial arsenic sulphide (average size $0.5 \mu \mathrm{m}$ ) with wet-process methods. Further investigations are in progress.

\section{Conclusions and Outlook}

The comparative studies of historical and modern synthetic arsenic sulphide pigments as well as the descriptions and recipes used to manufacture arsenic sulphide pigments in historical documentary sources have proven to be significant for the identification and a better understanding of this very complex and rarely found colorant.

Due to the great complexity of the artificial arsenic sulphide components which are caused by a number of reasons including 
the choice of starting materials, production method (condition of formation), preparation procedures (purification, classification etc.) and the preparation of the pigment for painting (e.g. pulverisation, grinding) it is to be expected that the future analyses of artificial arsenic sulphides in historical samples (e.g. mineral collections) and works of art will result in a wide range of compositions. It should be pointed out that until now artificial arsenic sulphide pigments prepared by the wet-process methods have not been identified in artworks. ${ }^{[4]}$

Grundmann and Rötter suggested that only arsenic sulphide particles molten and solidified from natural orpiment (demonstrated by natural orpiment inclusions in the glassy masses) are to be referred to as orpiment glass $\left(\mathrm{g}-\mathrm{As}_{2} \mathrm{~S}_{3}\right.$ isotropic and $\mathrm{X}$-rayamorphous). ${ }^{[2]}$ All other solidified arsenic sulphide particles derived from the cake and/or sublimate of an arsenolite and sulphur mixture (using different ratios) and/or natural orpiment (without natural orpiment inclusions) are to be called arsenic sulphide glass $\left(\mathrm{g}-\mathrm{As}_{\mathrm{x}} \mathrm{S}_{\mathrm{x}}\right.$, isotropic and $\mathrm{X}$-ray-amorphous). This terminology is based on the very recent thesis by Georgiev who studied the binary chalcogenides including the AsS system. [20] The successful use of Raman spectroscopy by Georgiev is in our case extremely significant since it shows that this method is an excellent option for the future differentiation between natural arsenic sulphides and arsenic sulphide glasses.

From the observations and results obtained from the newly discovered historical and modern samples of red artificial arsenic sulphide crystals and/or amorphous glass cakes it can be concluded that most if not all of the so-called 'artificial realgar', 'Rotglas', 'red arsenic', 'roter Arsenik', 'künstliches Realgar', 'Rubinglas', 'Rauschrot', 'Rubinschwefel', 'rotes Rauschgelb', 'red orpiment', 'rotes operment' etc. will turn out to contain members of the alacranite solid solution series with the end members $\left(\mathrm{As}_{8} \mathrm{~S}_{8}\right)-\left(\mathrm{As}_{8} \mathrm{~S}_{9}\right)$. It was also found that the occurrence of pararealgar on artworks and historical samples (e.g. collections) as a secondary photochemical reaction product is not exclusively linked with realgar, but can also form on members of the alacranite solid solution series $\left(\mathrm{As}_{8} \mathrm{~S}_{8}\right)-\left(\mathrm{As}_{8} \mathrm{~S}_{9}\right)$.

\section{Acknowledgements}

We are very grateful to Daniel Mod (Abteilung Archäologie, Landesmuseum Joanneum, Graz, Austria) and Dr. Hans-Peter Bojar (Abteilung Mineralogie, Landesmuseum Joanneum, Graz, Austria) for providing the spectacular historical samples of artificial arsenic sulphides. We are also very grateful to Dipl.-Min. Klaus Rapp (Munich) for his analytical support with SEM-EDX. This study is supported by the research project 'The Polychromy of Baroque and Rococo Sculptures and Retables in Germany' (Technische Universität München) which is funded by the Deutsche Forschungsgemeinschaft (DFG).

Received: October 3, 2008

[1] C. Rötter, Restauro. Zeitschrift für Kunsttechniken, Restaurierung und Museumsfragen 2003, 6, 114.

[2] G. Grundmann, C. Rötter, 'Artificial Orpiment': Microscopic, Diffractometric and Chemical Characteristics of Synthesis Products', Carolin Rötter et al. Auripigment - Studien zu dem Mineral und den künstlichen Produkten $=$ Orpiment - Studies on the mineral and the artificial products [= Materialien aus dem Institut für Baugeschichte, Kunstgeschichte und Restaurierung mit Architekturmuseum der Technischen Universität München, Eds. M. Schuller, E. Emmerling, W. Nerdinger], Anton Siegl, Fachbuchhandlung $\mathrm{GmbH}$, München, 2007.

[3] A. Wallert, Maltechnik-Restauro 90, 1984, 4,45 .

[4] E. W. FitzHugh, in 'Artists' Pigments - A Handbook of Their History and Characteristics', Ed. E. W. FitzHugh, Vol. 3, 1997, pp. 47-79.

[5] V. I. Popova, V. A. Popov, A. Clark, V. O. Polyakov, S. E. Borisovski, Zap. Vses. Mineral. Obshchest. 1986, 115, 360, in Russian.

[6] N. Eastaugh, V. Walsh, T. Chaplin, R. Siddal, 'Pigment Compendium: Optical Microscopy of Historical Pigments', Elsevier-Butterworth Heinemann, 2004, p. 129

[7] A. L. Emelina, A. S. Alikhanian, A. V. Steblevskii, E. N. Kolosov, Inorganic Materials 2007, 43, 95.
[8] H. T. Hall, 'The system Ag-Sb-S, Ag$\mathrm{As}-\mathrm{S}$, and Ag-Bi-S: Phase relations and mineralogical significance', $\mathrm{PhD}$ Thesis, Brown University, Providence, Rhode Island, 1966.

[9] G. W. Roland, The Canadian Mineralogist 1972, 11, 520

[10] R. Blachnik, A. Hoppe, U. Wickel, Z Anorg. Allg. Chem. 1980, 463, 78.

[11] A. H. Clark, Amer. Mineral. 1970, 55, 1338

[12] E. J. Porter, G. M. Sheldrick, J. Chem. Soc. Dalton Trans. 1972, 13, 1347.

[13] G. P. Kothiyal, B. Gosh, J. Crystal Growth 1976, 32, 29.

[14] P. Bonazzi, L. Bindi, F. Olmi, S. Menchetti, Eur. J. Mineral. 2003, 15, 283.

[15] T. B. Massalski, 'Binary Alloy Phase Diagrams', Eds. T. B. Massalski, H. Okamoto, Vol. 1, ASM International, 1990

[16] M. Richter, G. Grundmann, A. van Loon, K. Keune, A. Boersma, K. Rapp, 'The occurrence of artificial orpiment (dry process) in northern European painting and polychromy and evidence in historical sources', in Carolin Rötter et al. Auripigment - Studien zu dem Mineral und den künstlichen Produkten $=$ Orpiment - Studies on the mineral and the artificial products [= Materialien aus dem Institut für Baugeschichte, Kunstgeschichte und Restaurierung mit Architekturmuseum der Technischen Universität München, Eds. M. Schuller, E. Emmerling, W. Nerdinger], Anton Siegl, Fachbuchhandlung $\mathrm{GmbH}$, München 2007, pp. 167-192.

[17] P. Noble, A. van Loon, Art Matters Netherlands Technical Studies in Art 2007, 4, 19.

[18] A. Wallert, J. Dik, Zeitschrift für Kunsttechnologie und Konservierung 2007, 21, 38 .

[19] L. Sheldon, S. Woodcock, A. Wallert, 'Orpiment overlooked-expect the unexpected in 17th century workshop practice', ICOM Committee for Conservation 14th Triennial Meeting, The Hague, 2005, poster, p. 529.

[20] D. G. Georgiev, 'Molecular structure and intermediate phases in group $\mathrm{V}$ binary chalcogenide glasses', PhD Thesis, University of Cincinnati, Cincinnati, 2003. 